\title{
SOX2 Gene
}

National Cancer Institute

\section{Source}

National Cancer Institute. SOX2 Gene. NCI Thesaurus. Code C61136.

This gene is involved in embryonic development and in the determination of cell fate. 